\title{
ACTIVITY OF THE AQUEOUS EXTRACT FROM POLYMNIA SONCHIFOLIA LEAVES ON GROWTH AND PRODUCTION OF AFLATOXIN B1 BY ASPERGILLUS FLAVUS
}

\author{
Marina M. Pinto; Edlayne Gonçalez*; Maria H. Rossi; Joana D. Felício; Cláudia S. Medina; \\ Maria J.B. Fernandes; Isabela C. Simoni \\ Instituto Biológico, Centro de Sanidade Animal, São Paulo, SP, Brasil
}

Submitted: December 05, 2000; Returned to authors for corrections: January 15, 2001; Approved: June 20, 2001

\begin{abstract}
The aqueous extract from Polymnia sonchifolia leaves (AE) was tested for inhibitory activity on aflatoxin B1(AFB1) production and growth of Aspergillus flavus. The cytotoxicity of AE on Vero cells was also performed. Suspensions of A. flavus spores were inoculated into $50 \mathrm{~mL}$ of YES medium together with different concentrations of the AE. The aflatoxin B1 was extracted, analyzed by thin layer chromatography and quantified by photodensitometry. All the concentrations of AE induced inhibition of AFB1 production. The aqueous extract showed in vitro cytotoxicity to Vero cells only at concentrations above $500 \mu \mathrm{g} / \mathrm{mL}$.
\end{abstract}

Key words: aflatoxin B1, Aspergillus flavus, Polymnia sonchifolia, cytotoxicity

\section{INTRODUCTION}

Aflatoxins are mycotoxins produced by certain strains of Aspergillus flavus and Aspergillus parasiticus $(2,15)$. Ingestion of food highly contaminated with aflatoxins may originate acute toxicity including hepatotoxicity, teratogenicity, immunotoxicity and even death. In humans, ingestion of aflatoxins is associated with hepatotoxicity (15).

Plants have been known for their medicinal and antimicrobial properties since ancient times (9). The biosynthesis of aflatoxin B1 can be inhibited by extracts of certain plants that are toxic to fungi and may be useful in controlling the fungal growth and mycotoxin production (14). Extracts of plants, such as garlic and onion, effectively retard growth and aflatoxin production (5). Natural compounds such as flavonoids, stilbene, essential oils and others were also active in inhibition of aflatoxin production $(3,8,10,13)$.

Polymnia sonchifolia, a plant popularly known as "yacon", is cultivated in the Andean highlands. The aerial part of P. sonchifolia may contain antifungal and pesticidal compounds, as pesticides are not needed in the cultivation of yacon. Leaf extracts of $P$. sonchifolia presented potent antifungal activity and inhibited spore germination in Pyricularia oryzae (6).
This work reports the inhibitory activity of aqueous leaf extract from P. sonchifolia against Aspergillus flavus growth and aflatoxin B1 production, and citotoxicity to Vero cells.

\section{MATERIALS AND METHODS}

\section{Preparation of plant extract}

Leaves of $P$. sonchifolia were collected in Capão Bonito city, São Paulo state, Brazil and dried at $40^{\circ} \mathrm{C}$. Dried leaves were pulverized in mill (Condux) to obtain a fine powder. The powdered leaves $(100$ g) were extracted with water at room temperature for 5 hours. After filtration and removal of water, the extract was lyophylized (Flaxidry $\mathrm{mp}$ ). This aqueous extract (AE) was stored at $4^{\circ} \mathrm{C}$ until use.

\section{Culture conditions}

Aspergillus flavus IMI 190 (Internatinal Mycology Institute London) was grown on potato dextrose agar (Difco Laboratories, Detroit, Mich) plates for 10 days at $25^{\circ} \mathrm{C}$. The spore suspension used as inoculum was prepared washing the culture with sterile $0.01 \%$ solution of Tween 80 (Merck, Germany). The number of spores in suspension was determined through counting in a Neubauer Chamber.

\footnotetext{
* Corresponding author. Mailing address: Instituto Biológico, Centro de Sanidade Animal, Av. Cons. Rodrigues Alves, 1252. 04014-002, São Paulo, SP, Brasil. Telefax (+5511) 5087-1754, E-mail: goncalez@biologico.br
} 


\section{Aspergillus flavus growth and aflatoxin production}

The semi-synthetic YES culture medium was used for aflatoxin production (4). Suspensions of A. flavus containing $1.3 \times 10^{5}$ spores $/ \mathrm{mL}$ were transferred to $50 \mathrm{~mL}$ of YES medium containing different concentrations of $\operatorname{AE}(0,50,100,150$ and $200 \mathrm{mg} / \mathrm{mL})$. Four replicates were performed for each concentration. For production of aflatoxin B1, cultures were incubated at $25^{\circ} \mathrm{C}$ for 5 days. The cultures were filtered and submitted to drying at $50^{\circ} \mathrm{C}$ for 4 days. The weight of each mycelium was determined. The filtrate was treated three times with $25 \mathrm{~mL}$ of chloroform for extraction of aflatoxin. The extracts were combined, evaporated and the residue was dissolved in chloroform and made up to $1 \mathrm{~mL}$ in a volumetric flask. Five $\mu \mathrm{L}$ of AE replicate were spotted on silica gel-G thin layer plate (Merck, Germany) which were developed using chloroform:acetone 9:1 (v/v) as the solvent system. The concentration of aflatoxin $\mathrm{B} 1$ in each $\mathrm{AE}$ was determined by photodensitometry (Shimadzu, CS 9000) comparing the area of the spots samples with aflatoxin B1 standards (Sigma Aldrich, USA).

\section{Cytotoxicity assay}

African green monkey Vero cells (ATCC-CCL 81) were grown in Eagle's minimum essential medium (MEM) supplemented with $10 \%$ of fetal calf serum (FCS) (Cultilab, Brazil). The AE was dissolved in steril distilled water, diluted 1:1 (v/v) with MEM to a final concentration of $2,000 \mu \mathrm{g} / \mathrm{mL}$ and filtered through a $0.22 \mu \mathrm{m}$ Millipore membrane.

The method used for the cytotoxicity test was described by Itagaki et al. (7). Briefly, using a 96-well tissue culture microplate containing $0.1 \mathrm{~mL}$ of MEM in each well, $0.1 \mathrm{~mL}$ of the extract at $2,000 \mu \mathrm{g} / \mathrm{mL}$ was added to each well of column 1 . The extract was two-fold serial diluted until column 6 . The wells from columns 1 to 8 were seeded with $0.1 \mathrm{~mL}$ of MEM $10 \%$ containing $3.0 \times 10^{4}$ Vero cells. Two-fold serial cell dilutions were made from columns 8 to 11 , and the microplate was incubated for $72 \mathrm{~h}$ at $37^{\circ} \mathrm{C}$ in $5 \%$ $\mathrm{CO}_{2}$ atmosphere. The medium was removed and the cells were stained with $0.1 \mathrm{~mL}$ of $0.4 \%$ crystal violet solution (CVS) in methanol for $30 \mathrm{~min}$. The experiment was repeated three times. The quantitative analysis (colorimetric evaluation of fixed cells) was performed by the absorbance measurements in automatic microplate reader at 595nm (BIO-RAD, model $3550 \mathrm{UV})$. The relative percentage absorbance of each well was calculated considering the control wells, which contained no test material, as $100 \%$. The concentration of extract that inhibited $50 \%$ of growth $\left(\mathrm{IC}_{50}\right)$ was determined based on the concentrationresponse curves.

\section{Statistical analysis}

The significance of results was performed using one way analysis of variance (ANOVA) and Tukey-Kramer multiple comparisons test for $\mathrm{p}<0.05$ and $\mathrm{q}>4.457$.

\section{RESULTS AND DISCUSSION}

The effects of $\mathrm{AE}$ on the aflatoxin $\mathrm{B} 1$ production by A. flavus culture compared to the control are shown in Fig. 1. All concentrations of AE inhibited AFB1 production, and the inhibition was highly significant as measured by the ANOVA, (p $<0.0001$ ). The effect was concentration-dependent (Fig. 1). The Tukey-Kramer test, comparing the control with each AE concentration tested, demostrated the inhibitory effect due to $\mathrm{AE}(\mathrm{p}<0.001$ and $\mathrm{q}>4.457)$.

The correlation between fungus growth and AFB1 production can also be seen in Fig. 1. As detected by the Tukey-Kramer test, only the $200 \mu \mathrm{g} / \mathrm{mL}$ concentration inhibited significantly the fungal growth $(\mathrm{p}<0.01$ and $\mathrm{q}=6.057)$.

Cell culture systems provide rapid and inexpensive information for toxicity studies (12). The dose-response curve obtained for AE by crystal violet staining method using Vero cells is illustrated in Fig. 2. The data show that only concentrations of AE higher than $125 \mu \mathrm{g} / \mathrm{mL}$ inhibited the cell growth after $72 \mathrm{~h}$. The $\mathrm{IC}_{50}$ obtained from the curve was $863 \mu \mathrm{g} / \mathrm{mL}$, indicating that the AE from $P$. sonchifolia leaves was not cytotoxic to Vero cells. Further toxicity assays are necessary to establish the safe concentration.

The $P$. sonchifolia leaves may have one or more substances with inhibitory activity in the aflatoxin B1 production by Aspergillus flavus in laboratory conditions. All the tested concentrations inhibited aflatoxin production, and these

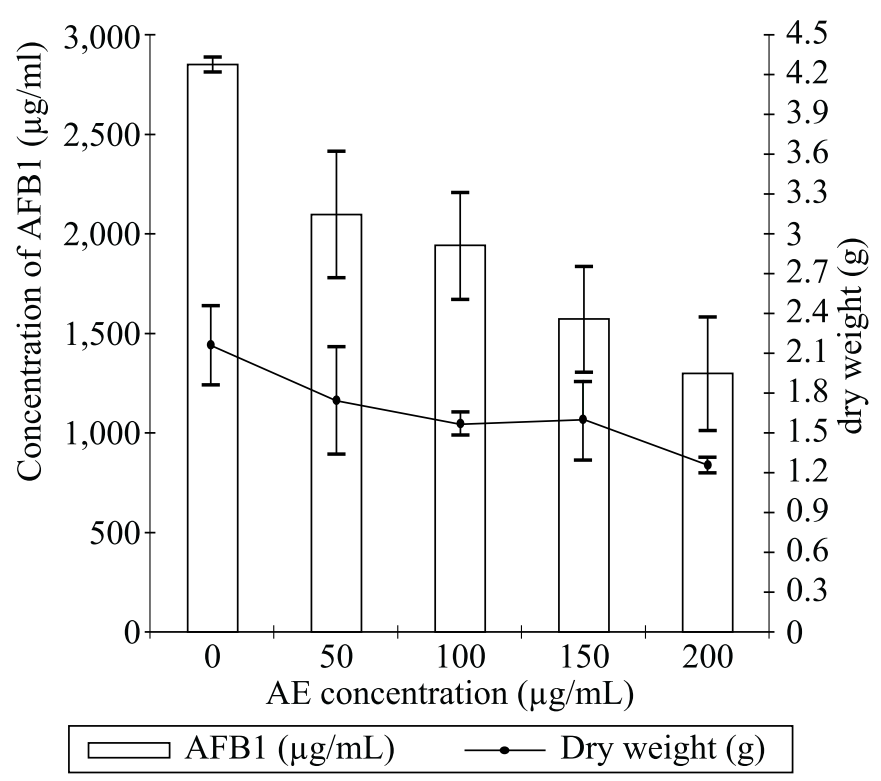

Figure 1. Production of aflatoxin B1 and growth of $A$. flavus in YES medium containing increasing concentrations of aqueous extract (AE) of $P$. sonchifolia. Production of AFB1 is expressed in $\mu \mathrm{g} / \mathrm{mL}$, growth is expressed in dry weight $(\mathrm{g})$ and results correspond to mean \pm S.D. 


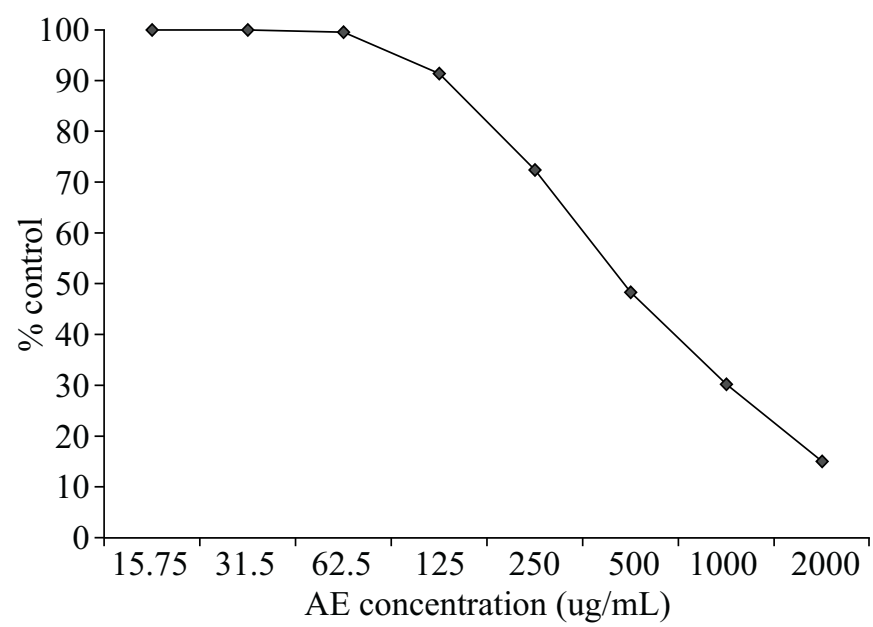

Figure 2. Dose-response curve of AE from P. sonchifolia on Vero cells growth. Data correspond to percentages of the control (100\%).

concentrations were not cytotoxic. These results suggest that AE may be acting in the fungal secondary metabolism, through the inactivation of some enzyme involved in the biosynthetic pathway $(1,15)$ or acting on the genic expression (11). Therefore, Polymnia sonchifolia could be a promising plant control production of aflatoxin $\mathrm{B} 1$.

\section{ACKNOWLEDGEMENTS}

The authors are grateful to Conselho Nacional de Desenvolvimento Científico e Tecnológico (PIBIC-CNPq) for the grant of Marina M. Pinto.

\section{RESUMO}

\section{Atividade do extrato aquoso de folhas de Polymnia sonchifolia no crescimento e produção de aflatoxina B1 por Aspergillus flavus}

Neste trabalho verificou-se a atividade do extrato aquoso de folhas de Polymnia sonchifolia no crescimento e na produção de aflatoxinas B1 por Aspergillus flavus. Suspensões de esporos de A. flavus foram inoculadas em $50 \mathrm{~mL}$ de meio de YES com diferentes concentrações do extrato aquoso. A aflatoxina B1 foi extraída e analisada por cromatografia de camada delgada e quantificada por fotodensitometria. Todas as concentrações testadas inibiram a produção de aflatoxina B1. O extrato aquoso apresentou citotoxicidade em células Vero somente em concentrações acima de $500 \mu \mathrm{g} / \mathrm{mL}$.

Palavras-chave: aflatoxina B1, Aspergillus flavus, Polymnia sonchifolia, citotoxicidade

\section{REFERENCES}

1. Bhatnagar, D.; Cleveland, T.E. Aflatoxin biosynthesis: developments in chemistry, biochemistry and genetics. In: Shotwell, O.L.; Huburgh, C.R. Aflatoxin in Corn: New Perspectives. Iowa: Rearch Bulletin 599, Iowa State University, 1991, p.391-405.

2. Bullerman, L.B. Inhibition of aflatoxin production by cinnamon. $J$. Food Sci, 39:1163-1165, 1974.

3. Bullerman, L.B.; Lieu, F.Y.; Seief, S.A. Inhibition of growth and aflatoxin production by cinnamon and clove oils. Cinnamic aldehyde and eugenol. J. Food Sci., 42(4):1107-1109, 1977.

4. Davis, N.D.; Diener, U.L.; Eldridge, D.W. Production of aflatoxin B1 and G1 by Aspergillus flavus in a semisynthetic medium. Appl. Microbiol., 14: 378-380, 1966.

5. Fan, J.J.; Chen, J.H. Inhibition of aflatoxin-producing by welsh onion extracts. J. food Prot., 62(4):414-417, 1999.

6. Inoue, A.; Tamogami, S.; Kato, H.; Nakazato, Y.; Akiyama, M.; Kodama, O.; Akatsuka, T.; Hashidoko, Y. Antifungal melampolides from leaf extracts of Smallanthus sonchifolius. Phytochemistry, 39(4):845-848, 1995.

7. Itagaki, H.; Hagino, S.; Kato, S.; Kobayashi, T.; Umeda, M. An in vitro alternative to the draize eye-irritation test: evaluation of the crystal violet staining method. Toxicol. In Vitro, 5(2):139-143, 1991.

8. Mallozzi, M.A.B.; Corrêa, B.; Haraguchi, M.; Brignani, F.N. Effect of flavonoids on Aspergillus flavus growth and aflatoxin production. Rev. Microbiol., 27:161-167, 1996.

9. Massod, A.; Ranjan, K.S. The effect of aqueous plant extracts on growth and aflatoxin production by Aspergillus flavus. Lett. Appl. Microbiol., 13:32-34, 1991.

10. Norton, R.A. Inhibition of aflatoxin B1 biosynthesis in Aspergillus flavus by anthocyanidins and related flavonoids. J. Agric. Food Chem., 47(3):1230-1235, 1999.

11. Payne, G.A. Molecular approaches for studying aflatoxin biosynthesis In: Shotwell, O.L.; Huburgh, C.R. (eds) Aflatoxin in Corn: New Perspectives. Iowa: Rearch Bulletin 599, Iowa State University, 1991, p.383-390.

12. Segner, H.; Lenz, D.; Hanke, W.; Schüürmann, G. Cytotoxicity of metals toward rainbow trout R1 cell line. Environ. Toxicol. and Water Quality an International Journal, 9: 273-279, 1994.

13. Sobolev, V.S.; Cole, J.R.; Dorner, J.W. Isolation, purification, and liquid chromatographic determination of stilbene phytoalexins in peanuts. J. AOAC, 78(5):1177-1182, 1995.

14. Steinhart, C.E.; Doyle, M.E.; Cochrane, B.A. In: Steinhart, C.E.; Doyle, M.E.; Cochrane, B.A. (eds). Food safety 1996. New York, Marcel Dekker, 1996, p.376-394.

15. Trail, F.; Mahanti, N.; Linz, J. Molecular biology of aflatoxin biosynthesis. Microbiology, 141:755-765, 1995. 